\title{
On the Ethics of War
}

\section{Iceal Averroes E. Estrella}

\begin{abstract}
One of the most influential and known view regarding the morality of war is the Just War Theory wherein certain requirements must be met in order to justify a war being fought by a state. The traditional Just War Theory judges wars in two principles, the justice of resorting into war in the first place, jus ad bellum and the justice in the conduct of war, jus in bello. Most just war theorists claim that the two must be independent of each other, that is, one may find himself in a war wherein the jus ad bellum is just, meaning the justice of war itself is just, while the jus in bello is unjust, and vice versa. This paper will tackle and evaluate the conditions given by the just war theory. Also, this paper will argue that jus ad bellum and jus in bello must be not be independent of each other when justifying a war. Jus in bello must follow from jus ad bellum and the two principles must be met before one can say that a particular war is just. The dependence of the two principles will also imply that the cause has a great bearing in determining whether a particular action or conduct in war is just or unjust. This will also be an argument against the "moral equality of soldiers."
\end{abstract}

Keywords: Just war theory, ethics of war, jus in bello, jus ad bellum

\section{Introduction}

$\mathrm{O}$

ne of the most influential and known view regarding the morality of war is the Just War Theory wherein certain requirements must be met in order to justify a war being fought by a state. The traditional Just War Theory judges wars in two principles, the justice of resorting into war in the first place, jus ad bellum and the justice in the conduct of war, jus in bello. Most just war theorists claim that the two must be independent of each other, that is, one may find himself in a war wherein the jus ad bellum is just, meaning the justice of war itself is just, while the jus in bello is unjust, and vice versa. This paper will tackle and evaluate the conditions given by the just war theory. Also, this paper will argue that jus ad bellum and jus in bello must be not be independent of each other when justifying a war. Jus in bello must follow from jus ad bellum and the two principles must be met before one can say that a particular war is just. The dependence of the 
two principles will also imply that the cause has a great bearing in determining whether a particular action or conduct in war is just or unjust. This will also be an argument against the "moral equality of soldiers."

One of the most unforgettable wars of the world is World War II. After Germany had lost the World War I, the Nazi leader, Adolf Hitler, was appointed as the Chancellor of Germany. He suspended civil liberties and removed other political adversaries and rose into a dictatorial power after the parliament building was burned down. He signed a treaty with Poland, a nonaggression treaty, in 1934. Wanting to retake the territory lost by Germany during the First World War, and to take all the Germans in surrounding countries, he invaded Poland and France, who signed treaty to protect Poland. France declared war on Germany and World War Two began. We all know that the Germans considered the Aryan race as the superior race and want to cleanse their race. They created concentration camps wherein they put the Jews into slavery and killed them through gas chambers and crematoriums. This is known as the Holocaust wherein six million Jews were captured and put to death only for the reason that they have a Jewish blood. Reading and knowing these facts make us think about the morality of such wars. It makes us also think whether such wars are just or unjust. We may even ask the question of really having a morality or not having a morality in war.

War as defined by the Prussian general and war theorist, Carl Von Clausewitz, is an extension of policy. For him, war is a means to implement a policy and it is a means to compel the enemy to do what you desire. War is used as an instrument of policy. Some of the early thinkers of the philosophy of war like Francisco de Vitoria said that "Difference of religion cannot be a cause of war...the sole and only just cause for waging a war is when harm has been inflicted." Many philosophers have dealt with the philosophy of war discussing about its nature, its cause and its morality. But we will be focusing on the ethics of war given the assumption that wars occur because policies are made and must be implemented. War is an activity wherein the victorious will be the one having the privilege of having its desired policy implemented.

\section{Views on the Ethics of War}

Three views are considered when talking about the morality of war. They are realism, pacifism, and the just war theory. Each of them has its own beliefs regarding the ethics of warfare. This paper will be discussing them and state what view it chose and the reason for choosing that particular view.

${ }^{1}$ Paul Christopher, The Ethics of War and Peace: An Introduction to Legal and Moral Issues (New Jersey: Prentice Hall, Inc., 1999).

(C) 2012 Iceal Averroes E. Estrella http://www.kritike.org/journal/issue_11/estrella june2012.pdf ISSN 1908-7330 
Realism. The realist says that we cannot find morality in war and that morality cannot be applied in war. "Realism is sometimes presented as the thesis that ethics does not apply to war." The realist believes that a state should always be thinking about its own national interest. A state should therefore do whatever it thinks to be beneficial to its national interest, even if it is to wage a war against other states. The state then must do whatever it takes to win the war and get what it wants, so morality is never applicable to war and international affairs. Realists believe that morality is for individual persons only and not for the state because the state's playground, the international ground, is harsh and the state needs to protect its people and its interest from other states. The state cannot therefore afford to apply morality when dealing with international affairs. Some of the prominent realists are Machiavelli and Thomas Hobbes.

There are two kinds of realism, descriptive realism and prescriptive realism ${ }^{3}$. Descriptive realism says that states cannot act morally in times of war or that states do not act morally in times of war. Descriptive realism described the international stage as a stage wherein morality cannot be applied. States in the international stage cannot or do not apply morality when interacting with one another because they are in a competition. Prescriptive realism says that the state ought to disregard morality when dealing with other state to protect its interest. This is because it is believed that states always do what's best for them and if a state applies morality when dealing with other states, this state will lose the fight for what it wants. So, states must not behave morally or must not consider morality when dealing with other states. One of the instances where a state deals with other states is in war.

Pacifism. The pacifist believes that we should never result into violence or war for whatever reason. Paul Christopher wrote that "The pacifist, abhorring the suffering caused by violence, concludes that war is consummate evil and rejects it under all circumstance. The pacifist argues that wars can never be morally justified and that we should not result into war no matter what." ${ }^{\text {" }}$

The roots of pacifism can be found and traced back with the early Christians where the use of violence is never permissible. Christian pacifist grounded their argument for never resorting to war from some passages in the New Testament of the Bible. Some of these passages, like Romans 12: 17-19, NIV, says that "Do not repay anyone evil for evil. Be careful to do what is right in the eyes of everybody. If it is possible, as far as it depends on you, live at peace with

2 Nigel Dower, The Ethics of War and Peace: Cosmopolitan and other Perspectives (Cambridge: Polity Press, 2009), 53.

${ }^{3}$ Brian Orend, "War," in The Stanford Encyclopedia of Philosophy (Fall 2008).

${ }^{4}$ Christopher, The Ethics of War and Peace, 1.

(C) 2012 Iceal Averroes E. Estrella http://www.kritike.org/journal/issue_11/estrella june2012.pdf ISSN 1908-7330 
everyone. Do not take revenge, my friends, but leave a room for God's wrath, for it is written: "It is mine to avenge, I will repay," says the Lord."

But Christians like Augustine and Ambrose will say that the early Christians misinterpreted some verses in the New Testament and will argue that violence against the wicked is sometimes necessary.

On the next chapter in the book of Romans, Chapter 13, we can see that God permits violence done by those who are in authority, in order for them to keep the peace and uphold justice. The pacifist's interpretations of the passages are to be imposed on the individual rather than to the state. The pacifist's argument on never to result in war should rather be an argument for an individual to never wage war against each other or to never make enemies with one another, given that their states are not in war. But these certain passages where the pacifist's arguments were founded should not be applied in state to state warfare. A state may wage war against another state if it is necessary. Authorities of the state, even Augustine will argue, have the authority to declare war on other states if it is to fight for the righteous. By this, we have identified the reasons why this paper opts not to choose the pacifist view on the ethics of war. The just war theory is somewhere between realism and pacifism and it has provided a more balance view on the ethics of war. Given the heaviness of the subject matter, the just war theory gave conditions on when wars are to be considered just and when are they considered unjust.

It is clear here that the pacifist and the realist are both on the extreme views with regards to the ethics of war. The third of these views regarding the morality of war is the just war theory which believes that sometimes wars are just and sometimes they are not. Even if war is evil, we can find morality in it. This paper chose to side on the just war theory as the more appropriate view in talking about the ethics of war and this will be the main focus of this paper. This paper chose the just war theory over the realist and the pacifist because it believes that there should be morality involved in committing such acts as war that takes away so many lives and has made a lot of people suffer and it also believes that sometimes war is necessary to maintain peace.

Just War Theory. The just war theory can be traced back to the teachings of Augustine, also known as the father of the just war theory. Augustine believes that "Just wars are usually defined as those which avenge injuries, when the nation or city against which warlike action is to be directed has neglected either to punish wrongs committed by its own citizens or to restore what has been unjustly taken by it. Further, that kind of war is undoubtedly just which God Himself ordain." ${ }^{p}$

5 Ibid. Paul Christopher was able to get this passage in Augustine's Questions in Heptateuchun, Book VI.

(C) 2012 Iceal Averroes E. Estrella http://www.kritike.org/journal/issue 11/estrella june2012.pdf ISSN 1908-7330 
"For Augustine, wars that are commanded by God are just and that God allows wars as a mean to punish the sinners. Augustine's just war was thus total and unlimited in its licit use of violence, for it not only avenged the violation of existing legal rights but also avenged the moral order injured by the sins of the guilty party regardless of injuries done to the just party acting as a defender of that order. As sins as well as crimes, seen in the context of a broadened concept of justice whereby not only illegal but immoral or sacrilegious acts were punishable, the transgressions were both a crime against the law and a sin against the righteous."

It is obvious here in this passage that Augustine is not a pacifist and that he considered violent acts towards the offenders of the law and to those who commit sins against the righteous permissible and just. War, therefore, for Augustine is a justified act provided that it has a right and just cause. Some examples of which are to punish the sinners and the violators of the law, to act as commanded by God, and to restore the moral order and peace. "...even wars might be waged by the good, in order that, by bringing under the yoke the unbridled lust of men, those vices might be abolished which ought, under a just government, to be either extirpated or suppresses." ${ }^{7}$

Philosophers like Saint Thomas Aquianas, Hugo Grotius, Suarez and Michael Walzer, also known as the dean of the contemporary just war theorists, have contributed in the development of the theory. Aquinas added to the equation that "...it was the subjective guilt of the wrongdoer that has to be punished rather than the objectively wrong activity." ${ }^{8}$ Hugo Grotius, however, removed the ideological considerations as the basis of just war and re-coursed it to self-defence as the basis of it. Suarez, said that the states should call the attention of the opposing side to the existence of a just cause and request reparation before action was taken. Michael Walzer, however, mostly tackled about the discrimination between combatants and non-combatants, non-combatants' immunity, aggression, the moral equality of soldiers, and the just cause. At the present time, the just war theory is mainly divided into three parts and are said to be independent of each other, meaning the justification for each are separate from one another.

The three main principles of the just war theory are jus ad bellum, jus in bello, and jus post bellum. But philosophers have often been more concerned on the first two principles. It is only recent that jus post bellum appeared into the debate.

\footnotetext{
${ }^{6}$ This statement of Frederick Russell was included in Paul Christopher's The Ethics of War and Peace.

${ }^{7}$ Ibid.

${ }^{8}$ Malcom Shaw, International Law, Sixth Edition (New York: Cambridge University Press, 2008), 1119
}

(C) 2012 Iceal Averroes E. Estrella http://www.kritike.org/journal/issue_11/estrella_june2012.pdf ISSN 1908-7330 


\section{THE ETHICS OF WAR}

\section{Jus ad Bellum}

The jus ad bellum is the principle which is concerned with the justification of resorting to war in the first place. It tries to find a justification whether the war was waged justly or unjustly. In Walzer's words, jus ad bellum is the "justice of war." "... dealing with jus ad bellum, which in its moral dimension was the primary concern of Augustine, was to establish rules governing the resort to war in the first place and to lay down conditions under which war could justifiably be waged."

Before one can be justified in resorting to war the following conditions should be met:

$S$ is justified in resorting to war, if and only if:

(1) S has a just cause why it resorted to war,

(2) $S$ is the proper authority to declare a war

(3) $S$ has the right intention for resorting into war

(4) $S$ declared the war as a last resort

(5) S has a high probability of success

(6) S measured the proportionality of the good the war will produce to its costs.

Condition (1) requires that the state must have a just cause in waging war with other states. How can we say that our cause in waging war is just? Waging a war against other states is only permissible according to Augustine if it is to punish the wrongdoers and to restore morality and peace. At the National Conference for Catholic Bishops, they stated that war is only permissible if it is to confront a "real and certain danger." ${ }^{10}$ For Walzer and most of the just war theorists, war is only permissible if it is to defend one's state from aggressors.

Michael Walzer said in "Just and Unjust Wars" that the state and the individual both have certain rights, the right to life and liberty for the individual, and the right for self determination and territorial integrity for the state and both forfeits their rights if they violate the rights of others. For the individual, they will lose their right if they bear or produce arms. If the state or the individual forfeits their rights, it is now justified for other states, or the victim state to go to war against that state who initiated the aggression. Also, if one bears or produces arms he loses his right to life and liberty and would be classified as a combatant. A state may wage war against a state who initiated the aggression against them.

\footnotetext{
${ }^{9}$ Jean Elshtain ed., Just War Theory (New York: New York University Press, 1992).

${ }^{10} \mathrm{Ibid}$.
}

(C) 2012 Iceal Averroes E. Estrella http://www.kritike.org/journal/issue_11/estrella june2012.pdf ISSN 1908-7330 
Condition (2) states that a war was justly waged or can be justly waged if it is declared only by the proper authorities to declare it, like the heads of states and not by an individual or a private group.

Condition (3) requires a state to have the right intention in waging a war and the only right intention for the just war theorists is the intention that supports the just cause. All intentions for waging a war must be directed for the just cause. Intentions like revenge, resource grabbing, or ethnic cleansing is clearly unacceptable.

Condition (4) states that all peaceful means must have been already tried to fix the conflict before one resorts into force.

Condition (5), the high probability of success, states that a state should ensure that they have a high probability of success before going into war.

Condition (6) requires the state to weigh in the proportionality of the benefits of war to its costs. A state is only just to resort to war if the benefits to be gain in war are proportionate or even larger that its costs. It means to say that the damage or the costs war brings must be outweighed by the good that will come out of it. Somehow, this condition is dependent on condition (1). This condition does not only involve the benefits and costs of the party waging a war but also to their opponents and other parties involved.

Each condition is necessary but not sufficient conditions to justify jus ad bellum. The six conditions should be met before one is considered justified in resorting to war.

Objection to Condition (4): This condition should not be followed in its strictest sense. It is for the reason that exhausting every possible peaceful means can be difficult for a state to do given the numerous means one can think of to resolve a conflict peacefully. No matter how hard one tries to exhaust every possible peaceful mean one can think of, one will surely miss out at least one possible mean to be tried. Also, a state being attacked by an aggressor does not have the luxury of time to exhaust all possible peaceful means to resolve the problem. An example of this would be, suppose that a county A is being attacked by country $\mathrm{B}$ who is, for some reason, determined to kill everyone in country A. Everyone in country A might have been killed already by the time country A finds a peaceful mean to resolve the problem, given that country B is determined to kill everyone in country A. This paper proposes that a state may not need to exhaust all possible means to resolve the problem peacefully before a war can be justly wage. A better requirement for this is that a state should at least try to resolve a conflict peacefully with at least two to three peaceful means before resorting into force. If a state refuses to resolve the conflict with that two to three means that one had tried, given that these means benefit both parties, then it means that the other party is not interested in peace negotiations and it can be said that that particular conflict in order to be resolved necessitates the use of force.

(C) 2012 Iceal Averroes E. Estrella http://www.kritike.org/journal/issue_11/estrella_june2012.pdf ISSN 1908-7330 
Objection to Condition (5): This condition is irrelevant and must be removed. Justification of why to resort to war based on the probability of success is not proper. Small states will have a difficulty achieving this condition. A small and weak state being aggressed and abused by a more powerful, larger, and stronger state seems just to fight back and wage war against the aggressor state even with a small probability of success.

With these conditions given by jus ad bellum, this paper has proposed that condition (4) must be revised into the condition that requires a state to at least try to resolve the conflict in a peaceful mean that is beneficial to both parties. It also stated that condition (5) is irrelevant to the justification on resorting to war in the first place and must be removed because it does not benefit the weaker and smaller states. I will add to these that condition (1) must be met first before moving into conditions (3) and (6). If condition (1) was not met, it will lead into having conditions (3) and (6) not to be met also. This is because conditions (3) and (6) are dependent on condition (1). Given this, it leads this paper to conclude that condition (1), having a just cause, is the condition that has the most bearing in justifying jus ad bellum. So it is very important that clear guidelines must be brought out in order for one to determine whether one has a just cause for resorting into war or not. "War is always judged twice, first with reference to the reasons states have for fighting, secondly with reference to the means they adopt." ${ }^{11}$ The next principle of the just war theory is concerned with the justification in the conduct of war, jus in bello.

\section{Jus in Bello}

Jus in bello is the principle of the just war theory that is concerned with the justification during the conduct of war. The condition that should be met for jus in bello are the following: ${ }^{12}$

The traditional jus in bello only has two conditions:

$S$ is justified in its conduct in war if and only if:

(1) S discriminated between combatants and non-combatants

(2) $S$ uses force proportional to the goal they want to achieve

Later just war theorist added the following conditions:

(3) S performs right treatment of prisoners of war

\footnotetext{
${ }^{11}$ Michael Walzer, Just and Unjust Wars (United States of America: Basic Books, Inc, 1977), 21.

${ }^{12}$ Ibid., 213.

(C) 2012 Iceal Averroes E. Estrella http://www.kritike.org/journal/issue_11/estrella june2012.pdf ISSN 1908-7330 
(4) S follows international rules on weapons prohibition

(5) $S$ does not use methods which are evil in themselves

(6) $S$ performs no reprisals

Condition (1) states that in the midst of battle only combatants are considered legitimate targets of an attack. One should know how to discriminate between non-combatants and combatants. Many philosophers have argued that in war we should distinguish the combatants from the non-combatants. This paper agrees that a clear distinction between the two should be discussed together with the appropriate justice they can get from their actions in times of war.

To have a clear distinction of the non-combatants from the combatants let us further examine on who qualifies as combatants. In the earlier discussion, we have seen in Walzer's explanation that an individual has a right to life and liberty and he looses this right if he bears arms or if he poses a threat to other's right to life and liberty. In other words, those who do not bear arms and those who do not show any threat to other individual's right to life and liberty are considered noncombatants. These are the civilians. While individuals like soldiers, who bear arms, are considered combatants which means that they do not have any right to life and liberty and they are considered a permissible target of an attack in war.

Discrimination between the combatants and non-combatants is very important in a war. The distinction given by Walzer, that anyone who bears arms and poses harm to others may not be enough to distinguish on who are to be considered as combatants.

Condition (2) is somewhat similar to the proportionality condition of jus ad bellum. In the essay of Robert Holmes entitled "Can War be Morally Justified?" he identified the proportionality requirement of jus in bello to be exactly similar to that of the jus ad bellum, that the cost or harm of war must be proportioned to the good it will bring. Some just war theorists clarified this by saying that the force to be used must be proportioned or be outweighed by the end it seeks.

Condition (3) states that we should treat Prisoners of War (POWs) well and with benevolence. They are not anymore to be considered combatants because they have been disarmed and are harmless.

Condition (4) restricts the use of weapons which are prohibited in the international law like Nuclear and Biological weapons. These are weapons which are hard to contain when used for an attack.

Condition (5) restricts the use of methods like genocide, rape, and other inhumane methods which are evil in themselves.

Condition (6) states that one should not take revenge with the other state with the same "jus in bello violation" method used against them.

Objections to condition (6): This condition is also irrelevant because it is obvious that when a state uses the same method used against them that violates jus

C 2012 Iceal Averroes E. Estrella http://www.kritike.org/journal/issue 11/estrella june2012.pdf ISSN 1908-7330 
in bello, whether it is for a revenge or not, they will too must have violated the jus in bello requirements.

\section{Jus post Bellum}

Jus post bellum is just new in the just war theory. It is concerned with the justification on the termination of war. This is still being debated upon and unsettled in the just war tradition. It proposes conditions as follows: ${ }^{13}$

There is justice in the termination of S's war if and only if:

(1) S creates proportional peace settlements with the enemy and it is publicly announced

(2) $S$ accounts for those who commit war crimes and punish them accordingly

(3) S's settlements secures basic human rights

(4) $S$ gives compensation and rehabilitation

Condition (1) states that peace settlements must be properly studied upon and be publicly announced.

Condition (2) states that those who commit war crimes must be tried in courts, and if found guilty, needs to serve the corresponding punishments.

Condition (3) states that the basic human rights must be restored

Condition (4) states that rehabilitation and compensation for damages must be served after the war.

Here we have seen the different conditions jus ad bellum, jus in bello, and just post bellum requires us to meet to justify each of the following principles of the just war theory. But we will be focusing more on the first two principles in our further discussion because this paper is more concerned with the morality involved during the war and why it begun in the first place. Given our present international laws, justice after the war can be served well. The gravity of morality involved in jus post bellum is lighter compared to the other two since just post bellum's concern is the justice after war which can be easily sought from and be met compared to the morality during the war itself which involves killings and deaths of thousands. I wonder how those people involved in an ongoing war can answer the questions "Am I doing the right thing?" "Am I fighting a just war?" "What are the effects of my action?"

In the earlier example about World War Two, we can say that Germany was not able to satisfy the jus ad bellum condition of a just cause and right

\footnotetext{
${ }^{13}$ Brian Orend, "Just and Lawful Conduct in War: Reflections on Michael Walzer," in Law and Philosophy, 20:1 (January 2001).

(C) 2012 Iceal Averroes E. Estrella http://www.kritike.org/journal/issue_11/estrella_june2012.pdf ISSN 1908-7330 
intention. Germany was not also able to satisfy the jus in bello condition of not using methods which are evil in themselves and the discrimination between the combatants and non-combatants because of what they did in the Holocaust, making their war unjust.

\section{Relationship between Jus ad Bellum and Jus in Bello}

War is always looked and judged upon in two separate principles, jus ad bellum and jus in bello. The two, jus ad bellum and jus in bello, they say, are logically independent of each other, meaning, as Walzer says it "It is perfectly possible for a just war to be fought unjustly and for an unjust war to be fought in strict accordance with the rules." ${ }^{.14}$ Other philosophers, however, believes that the two cannot be logically independent of each other.

Not much has been debated about the independence of jus ad bellum and jus in bello but some philosophers especially Michael Walzer and Jeff McMahan, have exchanges insights and arguments about the matter. Michael Walzer argues for the independence of jus ad bellum and jus in bello. For Walzer, the jus ad bellum is for the state and politician who wage war and the jus in bello is for the soldiers who fight in war. He believes that the violation of jus ad bellum cannot affect the justice in the conduct of war and that violation of jus in bello cannot affect the justice of war. He believes that combatants do not do wrong by fighting an unjust war, those who cannot meet the conditions of jus ad bellum. He claims that the rules of jus in bello both applies to just and unjust combatants, meaning both those who can and cannot meet the requirements of jus ad bellum. It is therefore possible for Walzer to fight unjustly in a just war and to fight justly in an unjust war. $\mathrm{He}$ claims that the killing of just combatants by unjust combatants can be justified if the unjust combatants followed the rules of war, jus in bello. Basically, he argues that jus in bello conditions can still be met even if the jus ad bellum requirements were not met.

But philosophers like Karma Nabulsi will say that "the justness of cause applies with equal force to both the origins and the conduct of war."15

Another philosopher, McMahan, will also argue about the dependence of the two principles. "McMahan argues that at the deepest moral level, considerations governing the justness of the war and those governing its conduct necessarily converge and are not independent of one another. Contra Walzer, McMahan denies the possibility of a war meeting the requirements of jus in bello

\footnotetext{
${ }^{14}$ Walzer, Just and Unjust Wars, 21.

15 Tamar Meisels, "Combatants: Lawful and Unlawful," in Laws and Philosophy, 26:1 (January 2007), 26.
}

(C) 2012 Iceal Averroes E. Estrella http://www.kritike.org/journal/issue_11/estrella june2012.pdf ISSN 1908-7330 
while violating those of jus ad bellum. Morally speaking, he argues one cannot fight "justly" in an unjust war."16

McMahan puts that civilians and soldiers also have their own responsibilities for participating in unjust wars. McMahan in his article "Unjust War" said that jus in bello and jus ad bellum cannot be logically independent of each other because "it is virtually impossible to participate in an unjust war without wrongdoing." ${ }^{17}$

McMahan is arguing here that we can never really satisfy the requirements of the jus in bello if we are fighting for an unjust cause because we cannot satisfy the jus in bello requirement of proportionality that says that the force or the harm we will bring will need to be outweighed by the end we want to achieve. It tells us that the end product or our goals must be greater or better than what we will do, and in order to satisfy this requirement we need to satisfy first the jus ad bellum requirement of a just cause. It is the jus ad bellum requirement of a just cause that will justify the end we seek in the jus in bello. Whatever end we may need to justify against the amount of force we applied, it will eventually lead us back into asking ourselves the question of what is the cause of our action, is it justified? It is the cause of why we want that certain end to be achieved. That cause gives a greater justification for the result of that action.

An example of this is that suppose we need to destroy a group of an enemy combatant's army and in order to accomplish this we applied a certain amount of force $\mathrm{X}$. But applying the amount of force $\mathrm{X}$ will surely wipe out or totally kill each and every soldier of the enemy's army. No one will be left injured. All enemy soldiers in that group will die instantly. Jus in bello will try to seek a justification for that action and will measure it in terms of the principle of proportionality. Now, can the mean we applied, applying the amount of force X, be outweighed by or is proportioned to our goal of destroying the group of an enemy's army? If we say yes, that the mean we applied is proportional to the end we seek, then the next question now is that how can we justify this? We can answer this if we have justified the jus ad bellum requirement. We can say that our mean of applying the amount of force $\mathrm{X}$ is justified because our goal to wipe out that certain group is justified by our cause in wanting to wipe out that group. However, if the cause is unjust, we cannot justify the mean we applied to be proportioned or to be outweighed by the end we seek. Therefore, one cannot satisfy the requirements of jus in bello without first referring back to jus ad bellum and satisfying jus ad bellum.

In addition to McMahan and other philosophers like Karma Nabulsi who believe that the two principles must not be logically independent, and following the line of McMahan's argument, This paper also argues that the first two

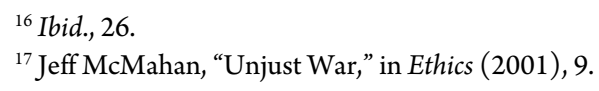

${ }^{17}$ Jeff McMahan, “Unjust War," in Ethics (2001), 9.

(C) 2012 Iceal Averroes E. Estrella http://www.kritike.org/journal/issue_11/estrella june2012.pdf ISSN 1908-7330 
principles of the just war theory cannot be logically independent, in fact, they are inseparable by arguing against Walzer's "Moral Equality of Soldiers" that was motivated by Walzer's claims that jus ad bellum and jus in bello are independent of each other. Also, this paper will argue that in order for a particular war to be just, the two principles must be met first. This will strengthen further the claim that the two principles are inseparable.

\section{Moral Equality of Soldiers}

The "moral equality of soldiers" states that combatants, regardless of their cause, just or unjust, have equal justifications in killing other combatants. Douglas Lackey on his review of Walzer's "Just and Unjust Wars" said that "Despite these parallels between Walzer's jus ad bellum and jus in bello doctrine, the "moral equality of soldiers" thesis produces a sharp separation between judgments about wars and judgments about soldiers. In Walzer's scheme, no soldier is good because his cause is good, and no soldier is bad because his cause is bad; the lives of soldiers on both sides are equally forfeit simply because they bear arms." 18

This is what this paper will try to disprove. This paper will argue against Walzer and say that there should be no "moral equality of soldiers" or moral equality of combatants. What determines if a combatant is just to kill an enemy combatant should come from his cause or intention in doing it, or jus ad bellum and not only if he plays the rules of the war game, jus in bello. Hedley Bull said in his essay, "When he comes to deal with jus in bello, Walzer provides us with a very sympathetic view of "the war convention." War is an activity governed by rules. These rules imply that soldiers are licensed to kill, and also that they are morally bound to "fight well" and especially bound to respect the rights of noncombatants. The rules of war apply equally to those whose cause is just and to those whose cause is unjust: soldiers fighting for an aggressor-state are not criminals, and soldiers fighting against an aggressor-state have no license to become criminals. The rights of non-combatants have to be upheld as much against the just as against the unjust." ${ }^{19}$

This paper agrees that the rights of non-combatants both in the just and unjust cause party must have equal rights and that they should never be a target of an attack in war. What this paper cannot agree on is that there should be equal rights for combatants both in the just cause and unjust cause parties. I cannot agree that because Walzer argues that, jus ad bellum and jus in bello are logically independent, combatants that are fighting in an unjust jus ad bellum war can be justified in killing or attacking combatants fighting in a just jus ad bellum war.

\footnotetext{
${ }^{18}$ Douglas Lackey, “A Modern Theory of Just War,” in Ethics, 3:3 (April 1982), 541.

${ }^{19}$ Hedley Bull, "Recapturing the Just War For Political Theory," in World Politics, 31:4 (July 1979), 593.
}

(C) 2012 Iceal Averroes E. Estrella http://www.kritike.org/journal/issue 11/estrella june2012.pdf ISSN 1908-7330 
Clausewitz puts war as a means to an end, which are policies. In war jus ad bellum seeks for an end while jus in bello is the means for that end. Clausewitz also said that the means can never be considered apart from its purpose. ${ }^{20}$ You cannot regard one as justified and the other as not justified in finding the morality of war. You should justify both of them in order to say that you are fighting a just war. It means that in order for a war to be totally justified they should both satisfy the conditions of jus ad bellum and jus in bello, altogether.

We should take into account the cause and the intention of the combatants for them to have as Walzer calls it a "license to kill." Combatants are only morally justified to kill an enemy combatant if their cause or their justification to resort to war in the first place is just, meaning they have satisfied the conditions of jus ad bellum. This paper will add to McMahan's argument about the dependence of jus ad bellum and jus in bello.

Suppose there is a state A that initiated an attack on state B because state A wants to get state B's resources. State A, who is fighting an unjust war, since they are the first to initiate the aggression and the one who violates state B's rights, sends their combatants to kill state A's combatants. State A fulfils all the requirements of jus in bello, they only targeted combatants, they did not use weapons that are prohibited by international laws, they use ample amount of force, they treat their prisoners of war well, they do not use weapons which are evil in themselves, and they are not doing it out of revenge, it may seem that state A's combatants are justified in killing state B's combatants because of Walzer's "moral equality of soldiers." but they are killing for the wrong or unjust reasons in the first place. If state B's combatants killed state A's combatants they are justified because they are just defending themselves and they are attacking on a state's combatants that have forfeited their rights. If non-mobilized combatants were attacked by enemy combatants, who initiated the aggression, will that not be considered unjust? It should not be the case that people with combatant status in war can be killed in any situation and still be considered as a just act for the reason that they are at war and they have a combatant status, therefore forfeiting their rights to life and liberty. But we should consider that the aggressor, who initiated the attack, and resorts to the unjust war in the first place, should only be the ones who to be considered forfeiting their rights to life and liberty. Combatants, who are just reacting to the aggression, and fighting a just war because what they are doing is just a defense, should not be considered as forfeiting their rights just because they bear arms. They can justly kill enemy combatants but they cannot be justly killed by enemy combatants.

${ }^{20}$ Carl Von Clausewitz, On War, trans. by J.J. Graham (Hertfordshire: Wordsworth Editions, 1997)

(C) 2012 Iceal Averroes E. Estrella http://www.kritike.org/journal/issue_11/estrella june2012.pdf ISSN 1908-7330 
Like for example in the case of the United States when they invaded Iraq, they have not met the requirements of jus ad bellum. The United States said that their reason for going to war with Iraq is to prevent Iraq from producing weapons of mass destruction and from preventing it to be used in the United States and its allies. It may be thought of that what the United States did was just, but the just war theory says that preventive attacks or preventive wars are not allowed. Because the United States is the one who initiated the attack to prevent an attack it makes them the aggressor state.

The United States did not have the support of the United Nations to go to war with Iraq but they did go to war with Iraq. The weapon of mass destruction, the reason why the United States said they would go to war with Iraq, was never found. It is commonly said that the hidden intention behind the United States' attack on Iraq is for their oil supplies. Because the United States was the aggressor state, it makes them fighting an unjust war. In this case, can we say that the combatants of the United States are just in their action in war in what they did in Iraq? Given the dualism between jus ad bellum and jus in bello, the United States' combatants may be just but if the two are not logically independent then the United States' combatants cannot be justified in their action in war because they are the ones who picked the fight first by initiating the war on Iraq, therefore having an unjust jus ad bellum.

One possible objection I see is that one might ask that if jus in bello should follow from jus ad bellum then it can be said that if you are fighting for a just cause or you are justified in resorting to war then whatever your actions or conduct might be during war, it will be just. I am not claiming that. I would like to emphasize that the conduct in war can only be justified if and only if the state met the requirements of both jus ad bellum and jus in bello. In the case of the earlier example, state B's combatants are only just in killing state A's combatants if and only if they adheres to the requirements set by jus ad bellum and jus in bello.

How about the soldiers who are just doing their jobs and do not know that their fighting in a war with unjust cause or a war with jus ad bellum violations since the state is the one who declares war? I believe that each person has its own moral responsibilities. Before one do things such as killing people one must have a right cause and a right justification in mind for doing it before he does it. He can always choose to do otherwise if he thinks that what he does is unjust. If he does not care whether his cause or his justification for doing it is just or unjust then it makes him more unjust. In the case in which the information one needs in order to know whether his war has just cause or not is not available to him, it does not make him justified in killing people as well. Not knowing the real reason behind killing an enemy combatant becomes an excuse rather than a justification. If you do not know the real reason behind what you are doing, that does not mean that your action is justified. 


\section{Satisfying the Two Principles}

Philosophers using the just war theory as a basis for evaluating a war has always viewed war in parts, in those two principles. One may wonder why they need to separate justifications for the two principles because it seems to me that it might be commonsensical for us to think that the conditions of the two principles must be met in order for a war to be "just." This paper will argue that the first two principle of the just war theory must be met before any particular war be labelled as a just war. Steps, this paper propose, should be made in evaluating a war. It must first satisfy the conditions of jus ad bellum before moving into satisfying the conditions of jus in bello. If one satisfies the requirements of both that is the time they can say that their war is just. One may be surprised to see that through research, one may fail to see someone arguing that in order for a war to be "just", conditions for both principles should be met. Meaning that both jus ad bellum and jus in bello conditions must be met first before saying that "This war is just!"

It is therefore wrong to say that, as Walzer says it, that "It is perfectly possible for a just war to be fought unjustly and for an unjust war to be fought in strict accordance with the rules. ${ }^{21}$ It is wrong because saying that statement assumes that the war is already just or unjust without considering the satisfaction of the jus in bello requirement. There should be a hierarchy of justification in war and jus ad bellum must be higher that jus in bello but conditions for both principles should be met before saying that the war is just or unjust.

The reason for this paper to say that jus ad bellum and jus in bello needs to be met before justifying a war is because conditions for jus in bello, in some sense, needs also to meet the requirements of a just cause, which is in jus ad bellum. This paper believes that the morality of war as a whole strongly depends on the just cause. Jus ad bellum and Jus in bello are inseparable because the latter must follow from the former. Jus in bello should follow from jus ad bellum since jus ad bellum holds the reason for why we resort to war in the first place. Our conduct in war should be justified first by our reason for the war. If at first they cannot satisfy the requirements of jus ad bellum, they cannot move into satisfying the requirements for jus in bello and thus they cannot justify their conduct in war. I am arguing that one cannot jump into justifying the conduct in war without justifying first on why to resort into war, it is a step by step process. If one fails to satisfy the requirements of jus ad bellum, then one has no right to evaluate or justify their war on the jus in bello level because their reason for going into war is unjust in the first place therefore whatever follows from that point cannot be justified.

It seems that if we grant the assumption that jus ad bellum and jus in bello are independent of each other then one can say that one who has unjust jus ad

\footnotetext{
${ }^{21}$ Walzer, Just and Unjust Wars, 21.
} 
bellum war can say that he is just in his conduct in war because he has met the requirements of jus in bello. This paper believes that by doing this we are just opening an opportunity for unjust aggressors to fool us, its enemy or even its own people, and make us believe that they are fighting a just war given that they are following the requirements of jus in bello but secretly violating the jus ad bellum's requirement of a just cause. This is because it is possible to fight justly in an unjust jus ad bellum war given the premise that the two principles are logically independent of each other.

Also, when a state violates the jus ad bellum requirements, especially the "just cause" of resorting to war and proportionality, it will follow that their intentions will be that of an "unjust cause." Given that, the actions or the conduct of this particular state during war is therefore being motivated by unjust cause and unjust intentions. It is therefore most likely that when a state violates the jus ad bellum requirement it would not hesitate to violate the jus in bello requirement. This paper believes that a conduct motivated by an unjust intention is unjust. This is evident in World War II when the Nazis, who had an unjust cause for waging a war against the Jews and other countries, did not hesitate in conducting an act such as the Holocaust.

\section{Conclusion}

We have discussed that the jus in bello must follow from jus ad bellum. Wars can only be considered just if and only if they satisfy the requirements of jus ad bellum and jus in bello. Those who cannot satisfy the requirements of jus ad bellum cannot proceed into justifying the jus in bello. Jus ad bellum cannot be independent from jus in bello in the sense that jus in bello follows from jus ad bellum. On an ongoing war, or on war, combatants who are fighting in a just jus ad bellum war are the only ones who have the "license to kill." They are the only ones who can kill enemy combatants and be just. Combatants who are fighting in an unjust jus ad bellum war cannot be just in killing their enemy combatants who are fighting a just jus ad bellum war, for a just cause, because their justification for resorting into war is not justified in the first place, or in the level of jus ad bellum. Therefore, they cannot push towards justifying their conduct in war, jus in bello.

Combatants, who are fighting in a just jus ad bellum war, like for example they are just defending themselves from an attack, cannot be considered forfeiting their rights to life and liberty while combatants who fights for an unjust jus ad bellum war, the one who initiated an attack, are the ones who should be considered as forfeiting their rights to life and liberty. It is because they are the ones who unjustly resort to war in the first place. They are the ones who initiated the aggression. Combatants who fight in a war with an unjust resorting to war, therefore, do not have the equal justification in killing an enemy combatant as the 
combatants who fight in a war with a just jus ad bellum do. By these, we have concluded that jus ad bellum and jus in bello cannot be independent of each other. Because of these arguments we presented and added to McMahan's arguments, we have strengthened our claims and arguments against Walzer's claim that jus ad bellum and jus in bello are independent of each other.

I end with these striking words from the Chinese philosopher, Sun Tzu: "The supreme act of war is to subdue the enemy without fighting."

Department of Philosophy, De La Salle University-Manila, Philippines

\section{References}

Bull, Hedley, "Recapturing the Just War For Political Theory," in World Politics, 31:4 (July 1979).

Christopher, Paul, The Ethics of War and Peace: An Introduction to Legal and Moral Issues (New Jersey: Prentice Hall, Inc., 1999).

Dower, Nigel, The Ethics of War and Peace: Cosmopolitan and other Perspectives (Cambridge: Polity Press, 2009).

Elshtain, Jean ed., Just War Theory (New York: New York University Press, 1992). Lackey, Douglas, "A Modern Theory of Just War," in Ethics, 3:3 (April 1982).

McMahan, Jeff, "Unjust War," in Ethics (2001).

Meisels, Tamar, "Combatants: Lawful and Unlawful," in Laws and Philosophy, 26:1 (January 2007).

Orend, Brian, "Just and Lawful Conduct in War: Reflections on Michael Walzer," in Law and Philosophy, 20:1 (January 2001).

,"War," in The Stanford Encyclopedia of Philosophy (Fall 2008).

Shaw, Malcom, International Law, Sixth Edition (New York: Cambridge University Press, 2008).

Von Clausewitz, Carl, On War, trans. by J.J. Graham (Hertfordshire: Wordsworth Editions, 1997).

Walzer, Michael, Just and Unjust Wars (United States of America: Basic Books, Inc, 1977), 21. 